\title{
Legal Theses of the Kraków Court of Appeal in 1940-1943
}

\begin{abstract}
The German occupiers abolished the Supreme Court in the General Government. In the Polish (nonGerman) judiciary sector, there was no court of the highest instance to ensure the unification of jurisprudence. The competence to ensure the uniformity of jurisprudence and resolve existing doubts and legal issues was transferred to the courts of appeal. The objective of the present article was to demonstrate the procedure and practice of issuing legal theses by the Court of Appeal in Kraków. The article also presents changes in the composition of the judges and the territorial jurisdiction of the Kraków Court of Appeal. Archival sources constitute the source basis of the work. We also resorted to the latest subject literature. The work is based mainly on the analysis of archival sources and legal acts, so the scientific methods typical of the history of law were applied.
\end{abstract}

Keywords: General Government; Nazi law; Nazi judiciary; The Second World War; Court of Appeal in Kraków, Polish (non-German) judiciary

Słowa kluczowe: Generalne Gubernatorstwo, prawo nazistowskie, sądownictwo nazistowskie, II wojna światowa, Sąd Apelacyjny w Krakowie, sądownictwo polskie (nieniemieckie)

\section{Introduction ${ }^{*}$}

The General Government (hereinafter referred to as: GG) was established by the Decree of the Führer and the Chancellor of the German Reich on the Administration of the Occupied Polish Territories of October 12, 1939, which entered into force on October $26,1939 .{ }^{1}$ The establishment of the GG was preceded by a period of the military administration. The decree of the Reich Chancellor was a legal act regulating the basic regime

* The present publication was elaborated as part of the research project entitled "Charakter prawny i rola tez prawnych uchwalanych przez polskie (nieniemieckie) sądy apelacyjne w Generalnym Gubernatorstwie w okresie II wojny światowej" financed by the National Science Center, Poland - under contract No. UMO2017/27/N/HS5/00812.

${ }^{1}$ Weh, Prawo Generalnego Gubernatorstwa, A 100. 
aspects of the General Government. This quasi-state, of an incompletely defined regime and international legal status, was created from the areas occupied by the German army, which were not incorporated into the German Reich. The German word "Nebenland" best describes the GG, as a peripheral country, factually meaning "colonial land". Initially, the General Government was divided into four districts: Kraków, Lublin, Radom, and Warszawa. In 1941, the fifth district of Galicia, with the capital in Lviv, was created from part of the Polish lands that had been occupied by the Soviet Union in 1939. ${ }^{2}$

In the GG functioned a dualistic model of the common judiciary: German and Polish (non-German). The German judiciary was established for people of German nationality and origin. It consisted of two court instances: German courts and higher German courts. It was supplemented by special courts adjudicating in many categories of criminal cases. From 1943 and onwards, these special courts were combined with the German courts. ${ }^{3}$ The second section of the common judiciary - the Polish (non-German) judiciary functioned for the remaining categories of the population living in the General Government. It was based on the judicial system functioning in Poland before the outbreak of World War II. ${ }^{4}$

The most important change introduced to the judicial system of the Second Polish Republic, once it was taken over in the GG by the German authorities, ${ }^{5}$ was the abolishment of the Supreme Court. Pursuant to the regulation on the Polish judiciary of 19 February 1940, the Supreme Court "will temporarily refrain from continuing its activities". ${ }^{6}$ In fact, the Supreme Court Liquidation Commission was established with the aim of smoothly removing the highest court from the judiciary. ${ }^{7}$ Therefore, within the framework of the Polish (non-German) judiciary ${ }^{8}$ established in the General Government,

\footnotetext{
${ }^{2}$ More about administrative issues of the GG: Dziobek-Romański, Organizacja administracji, 278-86; Kozyra, Okupacyjna administracja, 36-42.

3 Wrzyszcz, Okupacyjne sądownictwo, 43-59.

${ }^{4}$ Mielnik, Sądownictwo polskie (nieniemieckie), 62-7.

${ }^{5}$ In the General Government, the German occupiers created a two-tier model of common judiciary. One of the divisions, the German judiciary, was dedicated to people of German nationality and origin. Whereas the second - Polish (non-German), was based on the pre-war judicial system of the Second Polish Republic, and intended to cover cases of people of nationalities other than German. The legal bases for the operation of common judiciary in the General Government were as follows: Regulation on the reconstruction of the judiciary in the General Government of 26 October 1939 (Journal of the Regulations of the General Governor for the occupied Polish territories - Verordnungsblatt des Generalgouverneurs für die besetzten polnischen Gebiete [hereinafter as: Dz.RGGOP], no. 1, p. 4); Regulation on special courts in the General Government of 15 November 1939 (Dz.RGGOP, no. 6, pp. 34-6); Ordinance on German judiciary in the General Government of 19 February 1940 (Dz.RGGOP, part I, no. 13, pp. 57-63); Regulation on Polish Judiciary in the General Government of 19 February 1940 (Dz.RGGOP, part I, no. 13, pp. 64-8) [hereinafter as ROSPGG]; Regulation on the transfer of legal matters in the German and Polish judiciary of 19 February 1940 (Dz.RGGOP, part I, no. 13, pp. 68-71). German names of the legal acts are mentioned in the bibliography.

${ }^{6}$ ROSPGG, $\S 5$ sec. 2.

${ }^{7}$ More on this subject: Mielnik, Sadownictwo polskie (nieniemieckie), 63-4. This process was quite lengthy, judgments in which cassation appeals were lodged, and which could no longer considered due to the cessation of activities by the Supreme Court, were not returned to the courts until the first quarter of 1941 . ANK, SAK 747, no pagination. Letter from the head of the Regional Court in Rzeszów of 17 March 1941 to the head of the Court of Appeal in Kraków regarding the validity of the cases.

${ }^{8}$ On the Polish (non-German) judiciary: Lityński, Historia prawa, 21-3; Mielnik, Sadownictwo polskie (nieniemieckie); Sworzeń, Sądownictwo polskie; Sworzeń, Sędziowie w podbitym kraju; Szarycz, Sędziowie i sądy; Szulczyński, Sądownictwo polskie; Wrzyszcz, „O organizacji”. In German-language literature, the
} 
there were municipal courts, regional courts and courts of appeal. There were courts of appeal operating in each district of the General Government.

Within the common judiciary system of the Second Polish Republic, the Supreme Court performed the function of a cassation court exercising general judicial supervision over the judicature of common courts. ${ }^{9}$ With the liquidation of the Supreme Court, the Polish (non-German) judiciary was deprived of its competences. The possibility of submitting a cassation appeal against final judgments of Polish (non-German) courts was therefore excluded. Some of the remaining powers of the Supreme Court were taken over by the central (Central Justice Department in the Government of the GG) and district justice departments. Initially, the competence to ensure the uniformity of judicial decisions was not exercised at all in the General Government.

It was not until 23 November 1940 that Kurt Wille, head of the Justice Department in the Office of the Governor General (and after the administrative reform of the GG of the General Justice Department of the GG Government), made a decision to enable the courts of appeal to elaborate legal theses on important legal issues, whose role was to unify the judgments of Polish (non-German) courts by settling interpretation uncertainties arising from the application of the law..$^{10}$

The actual reason behind the delegation of powers to adopt legal theses to the appellate courts in the General Government was the complicated, unclear, and practically open legal system introduced by the German authorities. This legal system that consisted of non-hierarchical sources of law, issued by a large group of entities, that were superimposed on pre-war Polish law, was the aftermath of totalitarian law whose program assumptions were legal uncertainty and legal nihilism. ${ }^{11}$ As a result, in mid-1940, Polish (non-German) courts of all instances were addressing numerous questions to the German authorities, concerning the interpretation of conflicts and legal loopholes that arose mainly in the process of applying pre-war Polish law under the occupational legal system. ${ }^{12}$ German authorities at the central and district level in the General Government suffered from a lack of qualified clerical staff. Despite the operation of units dealing with Polish in justice departments, its real knowledge among German judges and officials was never excessive. Therefore, in the absence of the Supreme Court, it was decided to delegate the competence to resolve at least some legal doubts to appellate courts. In the General Government, the Polish (non-German) judiciary was subject to the supervision of the district administration, which meant that there were some differences in the

problems of the Polish (non-German) judiciary in the General Government weren't the subject of monographic research. The most important publication containing information on this subject is the study by Diemut Majer ("Fremdvölkische" im Dritten Reich). The issues related to the judiciary of the Polish Underground State (Szerkus, Die Sondergerichtsbarkeit) and the judiciary in the Polish territories incorporated into the Reich (Becker, Mitstreiter im Volkstumskamp) are much better studied.

${ }^{9}$ More on this subject: Malec, „Sąd Najwyższy”, 121-91.

${ }_{10}$ Mielnik, Sądownictwo polskie (nieniemieckie), 88.

${ }^{11}$ On the features and principles of totalitarian law: Turska, „Prawo państwa totalitarnego”, 21-34; Uruszczak, „Perwersyjne funkcje”, 681-707.

${ }^{12}$ For example, in the Lublin district, the head of the district justice department issued a circular dated 10 May 1940, in which he ordered that all legal questions be referred to the regional courts. The regional courts were to turn to the German authorities only in cases where they were not able to provide an answer to the issue that arose on their own, and in all other cases they were to provide answers themselves. APZ, POZ 1, k. 22. 
functioning of this division of the judiciary between individual districts. An example is the procedure for issuing legal theses, which was regulated differently in each of the courts of appeal.

The objective of the this article is to present the procedure and practice of issuing legal theses by the Court of Appeal in Kraków. The theses issued by the Kraków court in the field of criminal and civil law, their subject matter, the law they related to and statistics will all be indicated and discussed. The time frames of the article, covering the years 1940-1943, were determined by the dates of the first and last court decision on the basis of which the legal thesis were issued by the Court of Appeal in Kraków.

\section{The Court of Appeal in Kraków during the German occupation}

Kraków courts were reopened shortly after the German army entered Krakow. ${ }^{13}$ On September 22, 1939, the German court counselor Dr. Mnich, who was the plenipotentiary of the Reich Ministry of Justice for the judiciary (Beauftragte des Reichsjustizministeriums für die Justizangelegenheiten),${ }^{14}$ orally notified the employees of the Regional Court in Kraków that they would all be considered "re-admitted to the court service"15. A few days earlier, on 19 September 1939, similar information was provided to employees of the Court of Appeal in Kraków. This is how Judge Karol Gniewosz described the reopening of the Kraków Court of Appeal:

[...] the evacuation orders to the Court of Appeal in Kraków were issued on 3 September 1939, so this date can be considered the date of suspension of the court's activities. As for the actual activities undertaken, the exact date is difficult to establish. On 19 September 1939, a representative of the German judicial authorities arrived and summoned the judges and officials of the court of appeal who were present in Kraków to resume their offices. No written order was issued at that time, and this order was only communicated orally. From that date, the slow organization of the court of appeal began. Sessions were held in the court of appeal in the second half of October. Finally, we would like to point out that it was not until 1 March 1940 that, pursuant to para. (3) § $6 \mathrm{sec} .3$ of the regulation of 19 February 1940 on the Polish judiciary in the General Government, and as a result of the order of the Head of the District, Department of Justice in Krakow, that the following announcement (in German and Polish): "On 19 February 1940, pursuant to the regulation of the

${ }^{13}$ On the history of the Court of Appeal in Kraków: Kowalski, „Zarys historii”, 481-96; Kowalski, Sąd Apelacyjiny.

14 It was a temporary function related to the period of military administration. After the establishment of the German civil administration, Dr. Mnich became the head of the district justice department in Kraków, and in December 1939 he was replaced by Martin Nebesky. In the spring of 1940, the office was taken over by Fritz Müller, who held this position until the end of the occupation. ANK, SAK 45, no pagination. Orders of the head of the Justice Department at the Office of the Head of the Kraków District of November and December 1939.

15 ANK, SAK 363, no pagination. Letter from the head of the Regional Court in Kraków to the head of the Court of Appeal in Kraków dated 14 November 1940. 
General Governor on Polish judiciary in the General Government. Kraków, March 1, 1940 Head of the Justice Department at the Head of the District in Kraków was issued". ${ }^{16}$

The official launch of the judiciary, on new legal bases, took place only on 1 March 1940 - at least in relation to the Court of Appeal in Kraków. In November 1939, the acting president of the Kraków Court of Appeal was Dr. Henryk Matuziński, and from December this role was performed by judge Karol Gniewosz. ${ }^{17}$ Judge Gniewosz eventually became the head ${ }^{18}$ of the Kraków Court of Appeal, a function he continued to hold until the end of the occupation. The first task of the emerging Polish (non-German) judiciary was to prepare lists of people who were re-admitted to service. Court employees had to complete personal questionnaires, including information such as their Aryan origin, declared nationality, family status, military service, and membership in political and social organizations. ${ }^{19}$ It was also in November and December 1939 that actions against the Polish intelligentsia, including judges, began. At the end of December 1939, Konrad Frąckiewicz, judge of the Kraków court of appeal, was severely beaten and arrested. Two days after his arrest, he died. ${ }^{20}$

The Court of Appeal in Kraków, just like before the war, operated in the court building located at ul. Grodzka 52. The district justice department was also located at the same address. The criminal department was located in a tenement house at ul. Kanonicza 9.21 The organizational structure of the Kraków Court of Appeal during the occupation included: presidential secretariat; filing office; 1st criminal division with its secretariat, headed by judge Józef Podobiński; 2nd civil department with a secretariat chaired by judge Alfons Głowacz; court cashier; accounts department; library and archives. ${ }^{22}$

As of 31 May 1943, the Court of Appeal in Kraków employed sixty-three people, including eighteen judges. ${ }^{23}$ Compared to 1939 , the number of judges was reduced by five $^{24}$. Even at the beginning of 1942, twenty-two judges worked in the Kraków Court

${ }^{16}$ ANK, SAK 746, sheets 4452-3. Letter from the head of the Court of Appeal in Kraków of 17 September 1940 to the head of the Court of Appeal in Radom regarding the resumption of activities by the Court of Appeal in Kraków.

17 In the funeral chronicle of the "Dziennik Polski" 1961, nr 4 (5 I) K. Gniewosz was described in the following way: "He was characterized by great integrity, independence and goodness. He raised generations of judges. He was not only an outstanding and respected lawyer, but a man of high culture, with wide interests, especially a great expert and lover of French literature. K. Gniewosz played a particularly glorious role during the occupation, managing the Polish judiciary, defending the interests of Poles with courage and dedication."

18 In the circulation of documents in the Polish (non-German) judiciary, the term "head of the court" was used to describe the pre-war function of court president, which was a direct translation from the German Der Leiter des Gericht. For this reason, the article uses the historical name "head".

19 ANK, SAK 45, no pagination. Order of the head of the Department of Justice at the Office of the Head of the Kraków District No. 4/39 of 5 November 1939 on the questionnaire of judiciary employees.

${ }^{20}$ Dratwa, „Losy krakowskich sędziów”.

${ }^{21}$ ANK, SAK 223, no pagination. Letter from the head of the Court of Appeal in Kraków to the heads of regional courts of 11 March 1944 regarding the judge's examination.

${ }^{22}$ ANK, SAK 63, pp. 23-5. Official translation of the names into German.

23 ANK, SAK 155, no pagination. Questionnaire regarding employment at the Court of Appeal in Kraków as of 31 May 1943.

${ }^{24}$ They were: president Bronisław Sawicki; vice-presidents: Alfons Głowacz, Karol Gniewosz; judges: Adam Balon, Fryderyk Cieślewski, Bolesław Chocholski, Konrad Frąckiewicz, Bolesław Gardulski, Ulryk Gorzemski, Jan Jek, Władysław Kawa, Adam Kawęcki, Mieczysław Kolbuszewski, Jan Korzonek, Kazimierz Kwapiszewski, Wawrzyniec Lelek, Włodzimierz Łaba, Henryk Matuziński, Jan Ostręga, Mieczysław 
of Appeal, fifteen of which were judges working in the Kraków Court before the war. ${ }^{25}$ The panel of the judges was supplemented by three lawyers of Ukrainian nationality and judge Stanisław Wyrobek (judge of the Criminal Chamber of the Supreme Court prior to the outbreak of war), judge Adolf Eimer (judge of the Court of Appeal in Poznan before the war), judge Stefan Piątkiewicz (judge of the Regional Court in Kielce before the war) and pre-war Counselor of the General Prosecutor's Office, Jan Paruszewski (who, before the war, was the head of the department at the General Prosecutor's Office in Poznań).

From 24 April 1940 up until the end of the occupation, Włodymyr Zahajkewycz, a pre-war Ukrainian political activist and deputy speaker of the Sejm of the second term (1928-1930), held the office of the deputy head of the court. ${ }^{26}$ Among the judges adjudicating in the Kraków Court of Appeal, there were also two other Ukrainians: Wołodymyr Horbowy (a pre-war lawyer, an activist of the Ukrainian National Committee during the occupation period) ${ }^{27}$ and Grzegorz Luczakowski (previously the head of the German administration in the German Przemyśl, established in 1939).. ${ }^{28}$

Between 1942 and 1943, pre-war judge Jan Jek (Johann Jeck) entered the volkslist as Deutschtämmiger (of German origin), and after changing his nationality, he was delegated to work in the German Public Prosecutor's Office (Deutsche Staatsanwaltschaft) in Kraków while still remaining a full-time member of the Court of Appeal in Kraków ${ }^{29}$ Judge Aleksander Wolter was seconded to work in the Main Justice Department in the Government of the General Government, where he held the position of an expert and translator in matters related to Polish law. ${ }^{30} \mathrm{He}$ was also a delegate of the head of the district justice department during the judge examinations at the Kraków appelate district that took place from January 1943 onwards. ${ }^{31}$

In 1943, i.e. after the borders of the General Government were finally shaped and the judicial regions were adjusted to administrative divisions, the Kraków appellate district consisted of six regional courts (in Jasło, Kraków, Nowy Sącz, Przemyśl, Rzeszów (Reichshof) and in Tarnów) and eighty-one municipal courts. ${ }^{32}$ In terms of the number of

Pilarski, Józef Podobiński, Kazimierz Szyposz, Aleksander Wolter. After: Kalendarz Informator Sąowy na 1939 rok, 122.

${ }^{25}$ They were: head Karol Gniewosz; deputy head Volodymyr Zahajkiewicz; judges: Adam Balon, Adolf Eimer, Alfons Głowacz, Wołodymyr Horbowy, Jan Jek (Johann Jeck), Władysław Kawa, Adam Kawęcki, Mieczysław Kolbuszewski, Kazimierz Kwapiszewski, Wawrzyniec Lelek, Włodzimierz Łaba, Grzegorz Łuczakowski, Henryk Matuziński, Jan Parewski, Jan Ostręga, Stefan,Piątkiewicz Mieczysław Pilarski, Józef Podobiński, Aleksander Wolter, Stanisław Wyrobek. After: ANK, SAK 105, pp. 1-2. Status of all employees of courts of Kraków appellate district in 1942.

${ }^{26}$ Biographical note of W. Zahajkiewicz. In 1944 he evacuated from Kraków, initially staying in Vienna, he passed away in 1961 in Bavaria.

${ }^{27}$ The appointment of W. Horbowy as a judge of the Court of Appeal in Kraków was the subject of a post-war decision of the Supreme Court. cf. The judgment of the Supreme Court of 28 June 1946, IK 540/45.

${ }_{28}$ ANK, SAK 104, sheet 1. Status of all employees 39-40.

${ }^{29}$ ANK, SAK 156, no pagination. List of persons belonging to the German nation working at the Court of Appeal in Kraków. Among the judges working during the occupation who entered the Volkslist, there were also: Dr. Emil Krynicki (Municipal Court in Kraków; before the war, a judge at the Municipal Court Lwów Zamiejski).

${ }^{30}$ Wrzyszcz, Okupacyjne sądownictwo niemieckie, 289.

${ }^{31}$ ANK, SAK 223, no pagination. Minutes of judicial examinations of the Kraków appellate district.

${ }^{32}$ The individual judicial regions consisted of municipal courts:

Regional Court in Jasło -8 municipal courts: Biecz, Brzostek, Dukla, Frysztak, Gorlice, Jasło, Krosno, Żmigród; 
municipal courts, it was the largest appellate district in the General Government. ${ }^{33}$ In the $\mathrm{GG}$, the areas of court appellate districts were adjusted to the administrative division and corresponded to the areas of the respective districts. Compared to the pre-war area, the area of the Regional Court in Kielce was excluded, as it formed part of the newly created Radom appellate district, and so was the area of the Regional Court in Wadowice, which in most (apart from the municipal courts in Maków Podhalański and Kalwaria Zebrzydowska) was part of the area annexed by the German Reich. On the other hand, the area of the Regional Court in Przemyśl was included in the Kraków appellate district, including part of the municipal courts that in the pre-war times were located in the area of the Regional Court in Jasło (from the pre-war Lesko and Sanok districts). After the creation of the Galicia district in the General Government, the courts previously located in the Soviet occupation zone were included in the Kraków appellate district. On 15 October 1941, the municipal courts in Bircza, Dobromil, Lisko, Lutowiska, Niżankowice, Sieniawa and Ustrzyki Dolne started operating. The branch office of the regional court operating in German Przemyśl was transformed into the Regional Court in Przemyśl. ${ }^{34}$

\section{The procedure for issuing legal theses by the Court of Appeal in Kraków}

In the circular issued on 23 November 1940, Kurt Wille instructed the heads of district justice departments to prepare and organize adjudication offices at the respective courts of appeal. ${ }^{35}$ According to this instruction, in addition to drawing up legal theses from judgments, they were also supposed to examine court decisions in terms of their

Regional Court in Kraków - 20 municipal courts: Bochnia, Dobczyce, Jordanów, Kalwaria, Kazimierza Wielka, Kraków, Krzeszowice, Liszki, Maków, Miechów, Myślenice, Niepołomice, Pilica, Proszowice, Skała, Skawina, Słomniki, Wieliczka, Wiśnicz, Wolbrom;

Regional Court in Nowy Sącz - 10 municipal courts: Czarny Dunajec, Grybów, Krościenko, Limanowa, Mszana Dolna, Muszyna, Nowy Sącz, Nowy Targ, Stary Sącz, Zakopane;

Regional Court in Przemyś1 - 17 municipal courts: Baligród, Brzozów, Bircza, Bukowsko, Dobromil, Dubiecko, Dynów, Jarosław, Lesko, Lutowiska, Niżankowice, Pruchnik, Przemyśl, Rymanów, Sanok, Sieniawa, Ustrzyki Dolne;

Regional Court in Rzeszów - 12 municipal courts: Głogów, Kolbuszowa, Leżajsk, Łańcut, Nisko,

Przeworsk, Rozwadów, Rzeszów, Sokołów, Strzyżów, Tarnobrzeg, Tyczyn;

Regional Court in Tarnów - 14 municipal courts: Brzesko, Ciężkowice, Dąbrowa, Dębica, Mielec, Pilzno, Radłów, Radomyśl Wielki, Ropczyce, Tarnów, Tuchów, Wojnicz, Zakliczyn, Żabno.

33 According to Kurt Wille, the head of the Main Justice Department in the General Government, a large number of municipal courts in the Kraków appellate district, mostly single-member, resulted from the more densely populated rural areas in the district and the former Austrian judicial organization. AAN, MID 105, sheet 263. Kurt Wille's report on the judiciary in the General Government.

${ }^{34}$ ANK, SAK 46, no pagination. Order of the head of the Justice Department at the Governor's Office of the District of Kraków of 10 October 1941 on the opening of courts in the post-Bolshevik area 189/41.

35 APR, SAR 4, sheet 1. Order of the head of the Court of Appeal in Radom of 25 July 1941 regarding legal theses. 
fundamental significance for the general judicial practice. ${ }^{36}$ Ultimately, a structurally separate adjudication office was established only at the Warsaw Court of Appeal. In the remaining courts of appeal, only competences were regulated, which were exercised primarily by presidium offices or departmental secretariats. District heads of justice departments instructed the preparation of draft ordinances on the issuing of legal theses to the heads of courts of appeal.

In Kraków, judge K. Gniewosz consulted on the collection of decisions with the heads of criminal and civil divisions, who, in response, provided him with the summary opinion of the judges of both divisions on the issue in question. ${ }^{37}$ Opinions on the regulation of this issue were also exchanged between heads of courts of appeal ${ }^{38}$. On 21 January 1941, the head of the Court of Appeal in Kraków was the first in the entire General Government to issue an ordinance on legal theses..$^{39}$ On the basis of this ordinance, separate sets of court decisions were created in the criminal and civil departments.

Legal theses were entered into these collections, constituting an excerpt from the justification of the judgment or the decision of the court of appeal in those cases, in which the court decided on a questionable or complex legal issues. The legal theses of the Court of Appeal in Kraków were to contain a concise resolution of the legal issue, including a reference to the relevant legal provision and indication of the case reference number. The reporting judge was responsible for editing the legal thesis in consultation with the adjudication panel in the respective case, after the adjudicating panel had previously determined that the court's decision should be included in the collection of decisions. Collections of judgments were kept at the Court of Appeal in Kraków by the heads of divisions, or by a judge appointed by the chairman. The collection had the form of a file and was kept separately for each act of law. ${ }^{40}$

Every two months, the chairman of the department in the Kraków court of appeal was to present to the head of the court all theses included in the collection of decisions, in order to forward them to all courts in the Kraków appellate district. The decision on notifying other courts was made by the head of the Court of Appeal in Kraków, taking into account the requirement to establish uniform jurisprudence of lower courts in doubtful or divergent cases, and to determine the interpretation of legal provisions that were issued by the authorities of the General Government. The district justice department was also to be notified about the legal theses issued in relation to German legislation in the General Government. The collection of decisions was also to include theses from judg-

${ }^{36}$ APR, SAR 4, sheet 10. Letter from the head of the Court of Appeal in Warsaw regarding the case law office.

37 ANK, SAK 31, no pagination. Letter from the chairman of the 1st Criminal Division of the Court of Appeal in Kraków of 9 January 1941 regarding the management of the collection of decisions; Letter from the chairman of the 2nd Civil Division of the Court of Appeal in Kraków of 7 January 1941 regarding the management of the collection of decisions.

${ }^{38}$ ANK, SAK 31, no pagination. Letter from the head of the Court of Appeal in Warsaw to the head of the Court of Appeal in Kraków of 20 December 1940 regarding the case law office.

39 ANK, SAK 31, no pagination. Order of the head of the Court of Appeal in Kraków of 21 January 1941 regarding the collection of decisions.

40 Ibid.

Artykuły - Articles 
ments issued by the Court of Appeal in Kraków since the reopening of this court by the German authorities. ${ }^{41}$

The head of the Court of Appeal in Krakow, sending the order to the heads of regional courts and the heads of the local divisions in the Kraków appeal, notified them that also the regional courts and the regional divisions of regional courts were to send copies of their judgments in which the court decided on fundamental legal issues to the Kraków Court of Appeal. Decisions issued by the court in both the first and second instance could both be sent to the Court of Appeal in Krakow, nevertheless the judgments issued in the first instance only if they were legally binding. The decisions of the regional courts were to be sent in with full justification. The Kraków Court of Appeal then reached a decision to include a judgment in the collection of decisions, being also responsible for editing the content of the corresponding legal thesis. ${ }^{42}$

The ordinance of the head of the Kraków court did not contain any information about the binding force of the legal theses elaborated by the Court of Appeal in Kraków. The creation of a very limited group of entities initiating the issuance of a legal thesis, the procedure for issuing them, and exclusion of the possibility of asking legal questions (both abstract and specific), and developing theses only on the basis of legally valid judgments, meant that there was no need to regulate this issue further. It was also possible to introduce a relatively binding character of legal theses for the courts which submitted a legal question to the appellate court. However, this possibility was excluded in the Kraków appellate district. ${ }^{43}$

The solution adopted in the Kraków Court of Appeal corresponded to the procedure set forth in $\S 61$ of the pre-war regulations of the Supreme Court. ${ }^{44}$ According to it, each adjudicating panel of the Supreme Court, after resolving a fundamental legal issue, determined the legal interpretation in the form of a formulated thesis, which was part of the justification of the judgment. All judges of the chamber and the prosecutor's office were informed about the thesis by the Bureau of Jurisdiction, if the interpretation also applied to another chamber, the president of that chamber and judges were also informed about such thesis ( $\$ 62$ of the Regulations of the Supreme Court). Such legal theses could be included in the case law collections issued by the Supreme Court (Art. 42 usp). ${ }^{45}$

The editorial preparation of theses was vested in the individual departments, and therefore the civil and criminal theses were prepared in a different way. For example, the civil theses did not contain information about the adjudication panel, only the thesis

41 Ibid.

42 ANK, SAK 31, no pagination. Letter from the head of the Court of Appeal in Kraków of 31 January 1941 to the heads of regional courts and heads of branch divisions regarding the submission of judgments to the Court of Appeal in Kraków.

${ }^{43}$ The possibility of asking legal questions was allowed at the Courts of Appeal in Lublin and Warszawa. In the Court of Appeal in Radom, the adjudication panel could apply to the enlarged panel to resolve any legal doubts.

${ }^{44}$ Rozporządzenie Ministra Sprawiedliwości z dnia 1 grudnia 1932 r. Regulamin Sądu Najwyższego [Regulation of the Minister of Justice of 1 December 1932 Regulations of the Supreme Court] (Dz.U. 1932 nr 110 poz. 911) [hereinafter: Regulations of the Supreme Court], § 49.

${ }^{45}$ Obwieszczenie Ministra Sprawiedliwości z dnia 15 listopada 1932 r. w sprawie ogłoszenia jednolitego tekstu prawa o ustroju sądów powszechnych [Proclamation of the Minister of Justice of 15 November 1932 on the publication of a uniform text of the law on the system of common courts] (Dz.U. $1932 \mathrm{nr} 102$ poz. 863 , hereinafter: usp). 
itself, its legal basis and a brief justification. Criminal theses, however, did not contain a clear indication of the legal basis of the decision, but included the adjudication panel and attached the complete justification of the decision. All legal theses were based on the decisions of the appellate court, none of the decisions sent to the Kraków appellate court was considered as containing a resolution of a significant legal issue. The copies sent from the regional courts were supplemented with annotations, for example: "it is not suitable for inclusion in the collection of court decisions (the judgment is based solely on facts, without interpretation of legal provisions)". ${ }^{46}$

In line with the essence of the described institution, the copies of theses were submitted to the heads of regional courts and, through the district justice department, to the heads of courts of appeal in other GG districts. The heads of regional courts were obliged to notify their subordinate municipal courts about the content of the theses they received. If the legal thesis concerned the GG law, the district justice department was also to be notified. In one case, when a legal provision (Art. X of introductory provisions to the Code of Civil Procedure ${ }^{47}$ ) was binding only in the area of the Kraków appellate district, the legal thesis was not to be sent to the other courts of appeal. ${ }^{48}$

As a result of the archival search, we were able to identify 12 civil legal theses and 30 criminal legal theses issued by the Court of Appeal in Kraków. ${ }^{49}$ These theses come from various periods of the occupation from 1940 to the end of 1943. Legal questions regarding the resolution of legal issues were submitted to the head of the Kraków court of appeal as late, as in in mid- $1944 .^{50}$ Unfortunately, no separate reference numbers were introduced to identify the legal theses issued by the Court of Appeal in Kraków. There were also no separate statistics. Therefore, we found establishing the percentage of recovered legal theses difficult.

\section{Criminal legal theses}

As aforementioned the adopted criminal theses of the Court of Appeal in Kraków contained more information than the civil one, allowing us to determine the adjudication panel in cases where the respective legal thesis was established, and the prosecutors

${ }^{46}$ ANK, SAK 31, no pagination. Copy of the judgment of the Regional Court in Tarnów of 18 March 1941, I Ca 82/41.

${ }^{47}$ Rozporządzenie Prezydenta Rzeczypospolitej z dnia 29 listopada 1930 r. - Przepisy wprowadzające Kodeks postępowania cywilnego [Regulation of the President of the Republic of Poland of 29 November 1930 - Introductory provisions for the Code of Civil Procedure] (Dz.U. $1930 \mathrm{nr} 83$ poz. 652).

${ }^{48}$ ANK, SAK 31, no pagination. Letter from the chairman of 2nd civil department on legal theses of 21 February 1942.

${ }^{49}$ The archival search was primarily conducted in the National Archives in Krakow, search results were verified and supplemented by a query in the State Archives in Lublin, Radom, and Warszawa.

${ }^{50}$ In May 1944, attorney Kazimierz Boryczko from Myślenice asked the head of the Court of Appeal in Kraków, asking the full members of the civil division to issue a legal thesis on the application of $\S 841$ et seq. of the Austrian Civil Code. Judge K. Gniewosz replied that he did not find grounds for a legal thesis to be elaborated by the appellate court. ANK, SAK 31, no pagination. Letter of attorney K. Boryczko of 26 May 1944 on the application of the law. 
involved in these cases. Out of thirty legal theses discovered, eighteen were interpretations of substantive law provisions, and twelve concerned procedural issues. Only in one case the legal thesis was based on the law issued by the General Government, and it was about the validity of decisions, so it was a purely "technical", and not a "political" issue. This is due to the fact that most of the criminal law provisions issued by the GG assumed the sole jurisdiction of the German judiciary, as these provisions were introduced to protect German interests, and their violation usually meant that the German prosecutor's office referred the case to the competent German courts. Therefore, in judicial practice, there was no need for the Court of Appeal in Kraków to interpret the provisions of criminal law issued by the German authorities in the General Government.

Table 1. List of legal theses of the Court of Appeal in Kraków in criminal law ${ }^{51}$

Criminal theses

No.

Legal basis

Art. 21 of the Penal Code ${ }^{52}$ Art. $14 \S 1$ of the Penal Code

2 Art. 187 of the Penal Code
Date and ref.

no.

Judgment of the Any action adopted in self-defense, and aimed at countering Court of Appeal a direct, unlawful attack on one's own or other person's interests in Kraków of 23 December 1940, case ref. I KA $355 / 40$

Judgment of the Court of Appeal in Kraków of 28 January 1941, case ref. I KA 420/40

Judgment of the Court of Appeal in Kraków of 10 March 1941, case ref. I KA 282/40
(Art. 21 of the Penal Code) can be interpreted only as intentional and not as unintentional, since the person undertaking them wishes to commit it, and this person, at minimum, foresees the consequences of its action and agrees to them (Art. $14 \S 1$ of the Criminal Code).

In the event that both criminal acts defined in Art. 187 of the Penal Code were committed by one and the same person, this offence should be punished with only one penalty, unless the second of these two acts is presented as a component of another, completely separate crime, e.g. fraud (Art. 264 of the Penal Code).

1. If the mark invalidate a banknote consists of several parts, e.g. four holes punched in a banknote, only the removal of all these parts justifies a conviction for committing the crime defined by Art. 175 of the Penal Code, while the removal of only some parts may be regarded as an attempted crime.

2. If the prescribed method for invalidation of a banknote covers several parts, but the invalidation mark was executed only partially on the banknote, the banknote shall not be considered an invalidated banknote, and the removal of such incomplete invalidation mark in part or even completely does not fulfill the definition of the above-mentioned crime.

${ }^{51}$ Author's elaboration based on: ANK, SAK 31; ANK, SOK 3020; APL, SAL 13/5; APR, SAR 5.

${ }^{52}$ Kodeks karny z 1932 r. [The 1932 Penal Code] (Dz.U.R.P. 1932 nr 60 poz. 571). 
$\S 11$ ROSPGG Art. $468 \S 2$ of the $\mathrm{CCP}^{53}$

Art. $469 \S 1$ of the CCP

Art. $23 \S 1$ of the Penal Code

7 Art. 271 of the
Penal Code 8
Decision of the Court of Appeal in Kraków of 15 March 1941, case ref. I KZ 9/411
Decision of the Court of Appeal in Kraków of 28 March 1941, case ref. I Ko $53 / 41$

Judgment of the Court of Appeal in Kraków of 29 May 1941, case ref. I KA 282/41

Judgment of the Court of Appeal in Kraków of 16 June 1941, case ref. I KA 185/41

Judgment of the Court of Appeal in Kraków of 18 June 1941, case ref. I KA 176/41
The wording of the provision of $\S 11$ of the Regulation of the General Governor on the Polish judiciary in the General Government of 19 February 1940: "The decision of the regional court issued in the second instance is final" states without any doubt, that this provision recognizes as final only those decisions of the regional court, which were issued in the second instance, and therefore only those judgments that were issued as a result of consideration of a given appellate measure and constitute its settlement, because only in this case the relevant judgment remains in the second instance.2. The Code of Criminal Procedure (CCP) does not include "rejection" of the complaint by the Court which issued the decision appealed against. The only form of a court's negative response to a complaint permitted by the provisions of the CCP is, if the complaint does not meet the prescribed formal conditions, and the refusal to accept such a complaint is issued by the president of that court (Art. $468 \S 2$ of the CCP) or, if the submitted complaint meets these conditions, it forwards it to the appellate court (Art. 469 $\S 1$ of the CCP). ${ }^{54}$

Offenses, the investigation and prosecution of which depends on the request of the injured party, become ex officio offenses upon the submission of the request, therefore the subsequent renunciation of the prosecution by the injured party shall not entail any legal consequences.

The sale of a horse for trial with the intention of the subsequent, handing over as an authentic, altered certificate of the horse's identity - contingent on the final sale of horse - is already an activity directly aimed at the implementation of this criminal intention (an offense under Art. $23 \S 1$ in connection with Art. 191 of the Penal Code).

Art. 271 of the Penal Code gives protection to the owner of the forest, field (i.e. the farm), regardless of whether the forest or field is a hunting area, and whether the owner of the forest or field has the right to hunt on it, then the owner of the right to hunt and the owner of the right to fish in wild waters, as do persons authorized by these owners to guard their rights, and thus forest, field, hunting and fishing guards.

Whenever the case concerned is qualified under Art. $236 \S 1$ letter a of the Penal Code should be decided not by whether the injured or sick person was able to work only after the period of 20 days - as the Act does not mention anything about it but only whether the effects caused by the perpetrator's actions lasted throughout this period, in the form of an unhealed injury or health impairment.

${ }^{53}$ Kodeks postępowania karnego z 1928 r. [The 1928 CCP] (Dz.U. 1928 nr 33 poz. 313).

${ }^{54}$ ANK, SOK 3020, sheet 30. Letter from the head of the Court of Appeal in Kraków to the heads of regional courts of 11 March 1944 regarding the judge's examination. 
9

10

Art. $286 \S 2$ of the Penal Code
Art. 264 of the Penal Code Art. 187 of the Penal Code

Art. 163 of the Penal Code
Decision of the Court of Appeal in Kraków of 28 June 1941, case ref. I KZ 32/41

Judgment of the Court of Appeal in Kraków of 15 July 1941, case ref. I KA 390/41

Judgment of the Court of Appeal in Kraków of 29 July 1941, case ref. I KA 356/41

Judgment of the Court of Appeal in Kraków of 2 September 1941, case ref. I KA $426 / 41$
The decision of the regional court on the application to reopen the proceedings is not subject to appeal.

Conviction under Art. $286 \S 2$ of the Penal Code of the postman for failing to pay the addressees the amounts given to him by the superior and appropriating them, does not preclude him from being sentenced separately under Art. 187 in connection with Art. 291 of the Penal Code for forging signatures of addressees on postal money orders and checks and presenting them to the superior authority.

1. Whoever forges or alters a document in a fraudulent agreement with a person who then commits a fraud using this document, becomes guilty of complicity in the act of fraud (Art. 264 of the Penal Code); and these actions thus loses the character of a formal crime under Art. 187 of the Penal Code.

2. The use of a forged or altered document to commit fraud is an offense under Art. 264 of the Penal Code, and cannot therefore be qualified and punished at the same time as a formal offense under Art. 187 of the Penal Code.

1. A violent attack on a person or property (Art. 163 of the Penal Code) always occurs, where violence was used to achieve the intended goal. Any action directed against human life, bodily inviolability, human freedom, intrusion into someone else's home to overcome material obstacles or resistance, etc., will be considered use of violence.

2. The Act does not require individual participants of a crowd to act as a result of prior collusion, with a predetermined objective. The crowd referred to in Art. 163 of the Penal Code, may even be the result of a random concentration of a larger number of people.

3. Each participant of the crowd is responsible for the consequences resulting from the activities of the crowd. For the very hostile attitude of those participants of the crowd, who would not actively attack people or property, as revealed in the form of shouts or gestures, decides about their participation in the main attack.

Judgment of the Court of Appeal in Kraków of 3 September 1941 , case ref. I KA $479 / 41$

Art. 191 of the Penal Code
The identity of the criminal act is determined not by the detailed enumeration of items taken by the perpetrator, but by the identity of the fact of the committed crime.

Both the altering of the horse's identity card and its use as an authentic one, performed by one and the same person, constitute only one offense under Art. 191 of the Penal Code.
Judgment of the Court of Appeal in Kraków of 16 September 1941 , case ref. I KA 408/41 
15

---
Art. 129 of the
Penal Code
Art. 292 of the
Penal Code

17

\footnotetext{
Art. 72 of the CCP

Art. 582 letter c of the CCP

Art. 527 of the CCP

Art. 542 of the CCP

Art. VII of

the provisions introducing enforcement proceedings
}

Judgment of the Court of Appeal in Kraków of 16 September 1941, case ref. I KA $447 / 41$

Judgment of the Court of Appeal in Kraków of 25 September 1941, case ref. I KA $446 / 41$

Decision of the Court of Appeal in Kraków of 17 October 1941, case ref. I KA $357 / 41$
Exemption from punishment when the limits of self-defense are exceeded is possible only in very exceptional circumstances, namely only when the excess of that defense is so insignificant

that it is almost on the verge of legal self-defense.

Private persons who, at the request of the village foreman, assist him in the execution of the capture of an offender, ordered by the municipal office, act as deputies of official, within the meaning of Art. 129 of the Penal Code, and not as persons performing commissioned activities in the field of state or local government management, i.e. they are not officials within the meaning of Art. 292 of the Penal Code.

Pursuant to the provisions of the Criminal Code, a professional criminal is anyone who has made a profession from committing crimes, and reached a decision to have regular income from this source, in particular, it is one who committed the crime assigned that he or she is accused of under the influence of the intention to start a series of crimes from which that person was to establish its main or at least a secondary source of income. 2. A fishing enforcement guard must be approved and sworn in by the administrative authority and wear the official mark while performing his duties.

Decision of the Court of Appeal in Kraków of 9 November 1941, case ref. I Ko

$113 / 41$

1. The reconciliation referred to in Art. 72 and Art. 582 letter c of the CCP, is not a settlement within the meaning of Art. 527 of the Code of Civil Procedure, and therefore does not constitute an enforcement order; its content may only be used as evidence in civil proceedings,

2. The order to initiate the enforcement of fines, pecuniary penalties and court costs awarded to the State Treasury (court fees and costs of proceedings) is issued, as far as the execution of the judgment of the municipal or regional court as an appeal is concerned - the municipal court, and as far as the execution of any other of the judgment - the prosecutor of the regional court (Art. VII of the provisions introducing enforcement proceedings and Art. 542 of the CCP)

3. A private interested party shall submit an application for the initiation of enforcement in order to collect the costs of the proceedings adjudged in the case of a private complaint.

Decision of the Court of Appeal in Kraków of 7 March 1942, case ref. I Ko

$126 / 41$

Judgment of Court of Appeal in Kraków of 13 March 1942 , case ref. I KA $861 / 41$
An application for the initiation of enforcement to recover the costs awarded to a private party is submitted by that party, and not by the municipal court or the public prosecutor.

Exceeding the limits of self-defense may, under given conditions, constitute an unintentional act. 
Art. 160 of the Penal Code Art. $262 \S 3$ of the Penal Code

Art. 160 of the Penal Code
Art. 508 of the $\mathrm{CCP}$

Art. 576 of the CCP

\section{Art. 609 of the}

Art. $340 \S 5$ of the CCP

Art. $341 \S 1$ of the CCP
Art. 37 section 2 of provisions on court costs
Art. $464 \S 2$ of the

Art. 467 of the $\mathrm{CCP}$

Art. 487 of the CCP

Art. $505 \S 2$ of the CCP
Judgment of the Court of Appeal in Kraków of 9 April 1942, case ref. I KA 100/42 Judgment of the Court of Appeal in Kraków of 9 June 1942, case ref. I KA 225/42

Judgment of the Court of Appeal in Kraków of 8 August 1941, case ref. I KA $168 / 41$

Judgment of the Court of Appeal in Kraków of 30 June 1942, case ref. I KA 238/42

Decision of the Court of Appeal in Kraków of 3 October 1942, case ref. I KA $589 / 42$

Decision of the Court of Appeal in Kraków of 17 October 1942, case ref. I KZ $31 / 42$
Necessary defense, whenever kept within the limits of the law, may, among appropriate conditions, in the event of a directly imminent danger, also consist in a spoiling attack.

Who appropriates found property, knowing that the property was lost or abandoned by the man who obtained it by means of a crime, commits a crime under Art. 160 of the Penal Code, and not an offense under Art. $262 \S 3$ of the Penal Code.

Fencing stolen property under Art. 160 of the Penal Code can be committed only with an object acquired by crime, and not an object that the perpetrator acquires through some transaction, such as purchase, exchange, etc. And in exchange for an object he or she acquired through the crime.

The "expert opinions" referred to in Art. $341 \S 1$ of the CCP and submitted to the court are the opinions issued in the respective case, while those referred to in Art. $340 \S 5$ of the CCP, as "protocols of court hearing of experts" are protocols drawn up in other cases.

The fee paid in criminal proceedings against a civil claim is generally not refundable: the provision of Art. 37 section 2 of the provisions on court costs constitutes the sole exception to this rule.

The court or the president of the court (chairman of the division) may refuse to accept the complaint only if it was submitted late or if it was submitted by an unauthorized person (analogously to Art. 487 and Art. $505 \S 2$ of the CCP), or if the complaint against the refusal of the decision of the appellate prosecutor was not drawn by a lawyer, or if the complaint was not accompanied by a proof of payment or transfer of a deposit in the amount of one hundred zlotys (Art. $464 \S 2$ of the CCP) or, finally, if the complaint for bail acceptance, complaint against refusal to recover the term for cassation, or a complaint for compensation for unjust sentencing was not drawn by a lawyer (Art. 467 of the $\mathrm{CCP}$ ). A complaint against the decision refusing to reopen the proceedings is inadmissible.

Decision of the Court of Appeal in Kraków of 23 February 1943, case ref. I KZ $6 / 43$

Provisions of the Code of Criminal Procedure on the Law of the Poor (Art. 576, 508 of the CCP) do not apply to the deposit which, pursuant to Art. $464 \S 2$ of the CCP, the aggrieved party should attach to the complaint against the refusal decision by a prosecutor of the court of appeal (Art. $464 \S 2$ of the CCP)

Decision of the $\mathrm{CCP}$
Court of Appeal in Kraków of 20 July 1943 , case ref. I KZ 19/43
The judgment of the district court acting as a court of appeal, whose previous judgment, due to the admission of the application for the reopening of the proceedings pursuant to Art. 609 of the CCP was repealed and the case was remitted for re-examination, it is not subject to appeal and is final. 

CCP

30 Art. $464^{1} \S 2$ of
the CCP
Decision of the

Court of Appeal

in Kraków of 7

August 1943,

case ref. I KZ

$237 / 43$

Decision of the

Court of Appeal in Kraków of 7

August 1943,

case ref. I KZ

$21 / 43$
In the case of a minor, for whom it was found at the hearing, that after reaching the age of 13 , and before the age of 17 , he had committed the alleged act, without examination, and in accordance with Art. $622 \S 1$ of the CCP, the court should an acquittal judgment and pursuant to Art. $622 \S 1$ of the CCP in connection with Art. 633 and Art. 635 of the CCP, apply to such a minor the educational measures pursuant to Art. $69 \S 2$ of the Criminal Code

1. Pursuant to Art. $464^{1} \S 2$ of the CCP, the aggrieved party should attach the indictment to the complaint (Art. 67 of the $\mathrm{CCP}$ ) only if he has or she has not previously filed an indictment meeting the requirements of Art. 282 of the CCP.

2. The decision of the regional court dealing with a complaint under Art. $464^{1} \S 1$ of the CCP cannot be appealed against only if the regional court considered the complaint on the merits, otherwise, if the regional court does not accept the complaint for formal reasons, such a decision may be appealed against.

Among the published legal theses, two groups can be distinguished, concerning similar subjects. The first of them dealt with the issue of necessary defense, with four theses referring to it (theses $1,15,20,21$ ), while the second group was related to the forgery of documents (banknotes) - with five theses $(3,6,10,11,14)$. The 17 th thesis (I KA $357 / 41$ ), containing the definition of a professional criminal, had the largest significance for applying the law in the realities of occupation (namely Art. $60 \S 2$ of the Penal Code). The 1932 Penal Code did not introduce a legal definition of a professional criminal, because "these are notions [professionalism and habit - annotation by HM] of the kind that do not lend themselves to schematic treatment, but must be left to the judge's judgment in the particular case". ${ }^{55}$ In the General Government, this concept was significant for the process of applying the law, as it was the criterion for transferring the case to the German judiciary. All cases in which the conditions of recidivism, professional or compulsive crime were found, were to be transferred, and that at every stage of the proceedings, to the German prosecutor's office, which decided on the jurisdiction over such case. ${ }^{56}$

Table 2. List of judges participating in cases on the basis of which legal theses in the field of criminal law were formulated at the Court of Appeal in Kraków ${ }^{57}$

\begin{tabular}{|lccc|}
\hline Judge & Presiding & Reporting & In the bench \\
\hline Eimer Adolf & --- & --- & 4 \\
\hline Horbowyj Wołodymyr & --- & -- & 2 \\
\hline Jek Jan & 4 & 1 & 4 \\
\hline Kawęcki Adam & 4 & 2 & 7 \\
\hline Łaba Włodzimierz & 1 & 4 & 21 \\
\hline Ostręga Jan & --- & 1 & 4 \\
\hline Piątkiewicz Stanisław & --- & --- & 2 \\
\hline Pilarski Mieczysław & --- & 1 & 5 \\
\hline Podobiński Józef & 20 & 2 & 20 \\
\hline Wyrobek Stanisław & --- & 10 & 18 \\
\hline
\end{tabular}

${ }^{55}$ Makowski, Kodeks karny 1932, 181-4.

${ }_{56}^{56}$ Mielnik, Sąownictwo polskie (nieniemieckie), 328.

${ }^{57}$ Author's elaboration based on: ANK, SAK 31; ANK, SOK 3020; APL, SAL 13/5; APR, SAR 5. 
Legal theses in the field of criminal law were most often formulated by the adjudicating panel consisting of: judge J. Podobiński, the chairman of the criminal division, as the presiding judge of the adjudicating panel, judge S. Wyrobek as a reporting judge and judge W. Łaba as a member of the adjudicating panel. Judge S. Wyrobek, a pre-war judge of the Criminal Chamber of the Supreme Court, undoubtedly had the most experience in adjudicating in cases requiring legal interpretation, therefore, most often, i.e. ten times, he was appointed the reporting judge, whose duty was to formulate the thesis. The judges who had not worked in the Court of Appeal in Kraków before the war - W. Horbowy and S. Piątkiewicz were also the least frequent participants in adjudication panels that formulated legal theses, and they never acted as reporting judges.

Table 3. List of prosecutors participating in cases on the basis of which legal theses in the field of criminal law were formulated at the Court of Appeal in Kraków ${ }^{58}$

\begin{tabular}{|c|c|}
\hline Prosecutor & No of cases \\
\hline Franciszek Konieczny ${ }^{59}$ & 3 \\
\hline Feliks Krajewski & 8 \\
\hline Paweł Szuchiewicz & 2 \\
\hline Leon Kożuchowski & 2 \\
\hline Stanisław Müller & 8 \\
\hline
\end{tabular}

Feliks Krajewski and Stanisław Müller most often acted as prosecutors in the cases on which the legal thesis was based. Mieczysław Güntner, the head of the prosecutor's office of the Court of Appeal in Kraków during the occupation, did not appear in any of the $\operatorname{cases}^{60}$.

\section{Civil law legal theses}

What is predominant in the discovered legal theses concerning civil law are issues with procedural law. Compared to the theses in the field of criminal law, attention is also drawn to the large number of theses based on the GG law. In addition to the ordinance on the Polish judiciary of 19 February 1940, the Court of Appeal in Kraków also interpreted the provisions of the real estate transactions regulation of 27 March $1940^{61}$ and the regulation on seizure of private property of 24 January $1940 . .^{62}$ The legal theses in the field of civil law come entirely from the first period of the Polish (non-German) judiciary, the

\footnotetext{
58 Author's elaboration based on: ANK, SAK 31; ANK, SOK 3020; APL, SAL 13/5; APR, SAR 5.

59 Before the war, he was a prosecutor at the Court of Appeal in Poznań. Arrested on 16 April 1942, imprisoned in KL Auschwitz, where he was shot on 27 May 1942. Dębski, „Sędziowie polscy”, 27-8.

${ }^{60}$ ANK, SAK 105, k. 4. Status of all employees of courts of Krakówappellate district in 1942.

${ }^{61}$ Regulation on real estate transactions in the General Government of 27 March 1940 (Dz.RGGOP, part I, no. 23, pp. 115-7).

${ }^{62}$ Regulation on seizure of private property in the General Government (Confiscation Ordinance) of 24 January 1940 (Dz.RGGOP, part I, no. 6, pp. 23-27).
} 
last thesis was based on the judgment of 20 May 1941. No theses from the later period could be found.

Table 4. List of legal theses of the Court of Appeal in Kraków in civil law ${ }^{63}$

Civil theses

No.

1

Legal basis

Real estate

transactions

regulation of 27

March 1940 and

the Regulation on

seizure of private

property of 24

January 1940.

2 Art. 233 of the Civil Procedure Code

$(\mathrm{CPC})^{64}$

Art. 242 of the CPC

Art. 419 of the CPC

3 Art. 157 of the CPC Art. 196 of the CPC

4

Art. 2 of CPC

Art. 3 of the act on

the arrangement of agricultural debts

of 28 June 1939

(Journal of Laws, item 372)

$5 \S 14$ ROSPGG

Art.13 of the court fees Act

Art. 141 of the CPC
Date and ref. no.

Resolution of the

Court of Appeal in

Kraków of 20 June

1940, II Cz 58/40

Decision of the Court of Appeal in Kraków of 12 October 1940. II CZ 170/40

Judgment of the Court of Appeal in Kraków of 17 December 1940, II CA 206/40

Decision of the Court of Appeal in Kraków of 27 June 1940. II CZ 86/40 and of 30 January 1941. II CZ $34 / 41$

Decision of the Court

\section{Content of thesis}

Permission to enter in land registers concerning Jewish property requires the approval of the relevant administrative authorities only in cases where real estate is dealt in by way of inter vivos transactions as well as by way of enforcement, but there is no basis for accepting an entry in the Jewish property by inheritance.

The ordering of a joint hearing in several cases of the parties is not subject to a complaint to a court of second instance.

Art. 157 of the CPC, as a specific provision, cannot be applied by analogy to a case where a party or its statutory deputy is located in a specific, well-known locality, deprived of communication with the seat of the court due to war events, conversely so, when the party's (or its statutory deputy's) residence does not is known - when the general provision of Art. 157 of the CPC apply, and a motion to suspend the proceedings under Art. 196 of the $\mathrm{CPC}$ should be dismissed.

In view of the failure to open conciliation offices for the property matters of farm holders - general courts do not have jurisdiction to consider applications of holders of group A rural farms.
The claimant's failure to pay the fees provided for in $\S 14$ of the Regulation on Polish judicature for the further conduct of the case shall not result in the return of the claim or the appeal.

${ }^{63}$ Author's elaboration based on: ANK, SAK 31; ANK, SOK 3020; APL, SAL 13/5; APR, SAR 5.

${ }^{64}$ Kodeks postępowania cywilnego z 1930 r. [The 1930 Code of Civil Procedure] (Dz.U. $1930 \mathrm{nr} 83$ poz. 651). 
$6 \S 7$ of the Regulation of 27 March 1940 on real estate transactions
Decision of the Court of Appeal in Kraków II CZ 136/40

$\S 7$ of the regulation of 27 March 1940 on real estate transactions establishing the principle of "entry of a legal change subject to the requirement of a permit may not be made to the land register until there is a permit", refers to activities that occurred under the binding force of the said regulation, and not to legal acts concluded before the entry into force of the same, provided that, in accordance with applicable legal regulations, ownership was transferred from the seller to the buyer.

$7 \S 6$ ROSPGG Art. 199 of the CPC
Decision of the Court of Appeal in Kraków of 15 November 1940. II CZ 198/40

An announcement on the resumption of activities of a respective court, issued in the result of an order of the authorities of the General Government, is not tantamount to the procedural effects of the proceedings in individual disputes pending in that court.

$\S 11$ of the Polish judicature regulation of 1940

Art. 641, 724, 728 and 792 of the CPC

Art. 395 of the CPC

Art. X of provisions introducing the $\mathrm{CPC}$ CPC

\footnotetext{
$\S 4$ and $\S 8$ of the regulation of the General Government of 24 January 1940 on the seizure of private property
}

Decision of the Court of Appeal in Kraków of 9 September 1940 , II CZ 38/40

Judgment of the Court of Appeal in Kraków

II CA $1 / 41$

II CA 29/41

Decision of the Court of Appeal in Kraków

II CZ 60/41
Decision of the Court of Appeal in Kraków II CZ 31/41

The provision of $\S 11$ of the regulation on Polish judiciary in the General Government did not change the course of instance in special proceedings, where the laws provide for exceptional means of appeal to the court of appeal as the third instance.

The CPC is not aware of the allegation of "inaccuracy of the hearing" referred to in the appeal, consisting in the court's omission of certain evidence offered by a party or the assessment of evidence inconsistent with the party's claims.

The plaintiff's failure to appear at the hearing designated for the purpose of reconciling the parties in the process for separation from the table and bed may not result in the rejection of the statement of claim pursuant to Art. X. of provisions introducing the $\mathrm{CPC}$.

Provision of Article $141 \S 4$ of the CPC does not apply to cases where a letter brought by a lawyer as a party's representative is subject to mixed fees, i.e. a relative entry fee and a fixed fee for service under $\S 6$ of the regulation of the Minister of Justice of 17 December 1934.

Judgment of the Court Seizure and recovery of stray property by the authorities of Appeal in Kraków of 20 May 1941.

II CA 23/41 pursuant to $\S 8$ of reg. of GG of 24 January 1940 on the seizure of private property results in the termination of third party rights to this property and causes the dismissal of these people's claims.

What is noteworthy among the legal theses formulated by the Court of Appeal in the field of civil law, are those relating to the reality of the occupation and the legal regulations introduced by the German occupant. The first thesis of June 1940 referred to issues related to the transactions in real estate belonging to the Jewish population. The regulation on real estate transactions issued by the General Government and the regulation on seizure of private property introduced the legal framework for the plunder of Jewish property, primarily real estate. The Court of Appeal in Kraków interpreted the provisions of the regulation on real estate transactions, pointing out that obtaining a proper permit is 
not necessary in the case of inheritance (II Cz 58/40). ${ }^{65}$ Another legal thesis (decision II CZ 136/40) interpreting the provisions of the regulation on real estate transactions concerned intertemporal issues - according to the Court of Appeal in Kraków - a permit was not required to make an entry in the land register, if the legal act was concluded before this regulation entered in force. The last legal thesis of May 1941 (judgment II CA 23/41) also concerned the law of the General Government. The Court of Appeal in Kraków interpreted the regulation on seizure of private property, assuming that the confiscation and recovery of stray property pursuant to $\S 8$ of the regulation resulted in the termination of third party rights to this property, and the resulting dismissal of these persons' claims.

\section{Conclusion}

The institution of legal theses was used to standardize judicial decisions in the General Government. Similar to the other courts of appeal the Court of Appeal in Kraków issued its own legal theses. They were similar in nature to the legal theses of the Supreme Court, published before the war in the "Collection of Supreme Court judgments" compiled by the Office of Jurisprudence of the Supreme Court. The procedure for issuing legal theses adopted in the Kraków court of appeal was the most limited, when compared to other courts of appeal. It was possible to issue a legal thesis only on the basis of a final judgment, the possibility of asking the court of appeal legal questions, issuing legal opinions or presenting legal issues to enlarged panels was excluded. Despite the fact that the possibility of issuing a legal thesis on the basis of a legally valid decision of a regional court was allowed, such a possibility was never exercised. The heads of the criminal and civil departments did not notice any important interpretations of the law in any of the cases sent for evaluation. The legal theses of the Kraków court of appeal were non-binding statements of the court of highest instance. They were sent to courts of appeal in other districts. The heads of courts of appeal, provided that they decided that a thesis from another court was of significant importance in the practice of applying the law, sent it to the courts subordinated to them. The method of keeping the collection of legal theses and the preserved archival material allowed us only for the analysis of panels adjudicating in criminal cases. This analysis demonstrated that only the most experienced judges participated in adjudicating cases in which a significant interpretation of legal provisions was carried out.

Legal theses in the field of criminal law mainly concerned pre-war Polish regulations, namely the 1932 Penal Code and the 1928 Code of Criminal Procedure. On the other hand, most civil law theses resolved issues arising in connection with the application of German legislation in the General Government. In case of both types of theses, we witness the resolution of doubts raised in connection with the reality of the occupation and the policy pursued by the German occupant. What belongs here are the theses in which

${ }_{65} \S 1$ of this regulation states that: "the permission of the authorities was required for 1) the transfer of ownership or encumbrance of the property by legal action, as well as for the transfer or encumbrance of rights to the property and rights to the property by legal action." 
the term "professional criminal" was defined, or the provisions of the real estate regulation or the regulation on seizure of property were interpreted.

The question that should be asked in relation to the subject matter concerns the actual impact of legal theses on the jurisprudence of Polish (non-German) courts. In the General Government, the access to official law publications and legal literature was a formidable issue. For example, in 1943, no bookstore in Kraków had the ABGB text or textbooks on substantive and procedural civil law available, and in the library of the Regional Court in Kraków there was only one copy of the Austrian Civil Code of 1811 in the Dbałowski edition. ${ }^{66}$ The problem of access to the sources of law appears in each of the GG districts. The interpretations of the courts of appeal certainly broadened the knowledge of judges of courts of lower instances. Examples from other districts demonstrate that legal theses were also used as arguments in pleadings submitted by parties, also in proceedings in front of German courts. ${ }^{67}$ Legal theses had to be disseminated also among attorneys in law proceedings.

\section{Bibliography}

\section{Archival sources}

Archiwum Akt Nowych, Ministerstwo Informacji i Dokumentacji Rządu RP [emigracyjnego] w Londynie, sygn. 105. [AAN, MID 105]

Archiwum Narodowe w Krakowie, Sąd Apelacyjny w Krakowie 1919-1950, sygn. 31. [ANK, SAK 31]; sygn. 45. [ANK, SAK 45]; sygn. 46. [ANK, SAK 46]; sygn. 63. [ANK, SAK 63]; sygn. 104. [ANK, SAK 104]; sygn. 105. [ANK, SAK 105]; sygn. 155. [ANK, SAK 155]; sygn. 156. [ANK, SAK 156]; sygn. 223. [ANK, SAK 223]; sygn. 363. [ANK, SAK 363]; sygn. 746. [ANK, SAK 746]; sygn. 747. [ANK, SAK 747]

Archiwum Narodowe w Krakowie, Sąd Okręgowy w Krakowie 1939-1945, sygn. 3020. [ANK, SOK 3020]

Archiwum Państwowe w Lublinie, Sąd Apelacyjny w Lublinie, sygn. 13/6. [APL, SAL 13/6]

Archiwum Państwowe w Radomiu, Sąd Apelacyjny w Radomiu 1939-1945, sygn. 4. [APR, SAR 4]; sygn. 5. [APR, SAR 5]

Archiwum Państwowe w Zamościu, Prokuratura Okręgowa w Zamościu 1940-1944, sygn. 1. [APZ, POZ 1]

\section{Printed sources}

Dziennik Polski 1961, no. 4 (5 I).

Kalendarz Informator Sadowy na 1939 rok, wyd. Jerzy Kirczenko, Marian Kraczkiewicz i Kazimierz Rudzisz. Warszawa: Biblioteka Prawnicza, 1939.

Weh, Albert. Prawo Generalnego Gubernatorstwa w układzie rzeczowym z objaśnieniami i szczegółowym skorowidzem. Kraków: Institut für Deutsche Ostarbeit, 1941.

${ }^{66}$ Mielnik, Sadownictwo polskie (nieniemieckie), 288-9.

${ }^{67}$ Mielnik, „Prawo sprawdzenia”, 235. 


\section{Judicial decisions, judgements}

Judgment of the Polish Supreme Court of 28 June 1946. Criminal Chamber File no. K 540/45. https://iura.uj.edu.pl/dlibra/publication/1030/edition/418/content?ref $=$ desc \&q=540 [(access date: 23.10.2020)].

\section{Legal sources}

\section{Polish legislation}

Rozporządzenie Prezydenta Rzeczypospolitej z dnia 19 marca 1928 r. Kodeks postępowania karnego [Regulation of the President of the Republic of Poland of 19 March 1928, Code of Criminal Procedure] (Dz.U. $1928 \mathrm{nr} 33$ poz. 313).

Rozporządzenie Prezydenta Rzeczypospolitej z dnia 29 listopada 1930 r. Kodeks Postępowania Cywilnego [Regulation of the President of the Republic of Poland of 29 November 1930, Code of Civil Procedure] (Dz.U. 1930 nr 83 poz. 651).

Rozporządzenie Prezydenta Rzeczypospolitej z dnia 29 listopada 1930 r. Przepisy wprowadzające Kodeks Postępowania Cywilnego [Regulation of the President of the Republic of Poland of 29 November 1930, Introductory provisions for the Code of Civil Procedure] (Dz.U. $1930 \mathrm{nr} 83$ poz. 652).

Rozporządzenie Prezydenta Rzeczypospolitej Polskiej z dnia 11 lipca 1932 r. Kodeks karny [Regulation of the President of the Republic of Poland of 11 July 1932, Penal Code] (Dz.U. 1932 nr 60 poz. 571).

Obwieszczenie Ministra Sprawiedliwości z dnia 15 listopada 1932 r. w sprawie ogłoszenia jednolitego tekstu prawa o ustroju sądów powszechnych [Proclamation of the Minister of Justice of 15 November 1932 on the publication of a uniform text of the law on the system of common courts] (Dz.U. $1932 \mathrm{nr} 102$ poz. 863).

Rozporządzenie Ministra Sprawiedliwości z dnia 1 grudnia 1932 r. Regulamin Sądu Najwyższego [Regulation of the Minister of Justice of 1 December 1932 - Regulations of the Supreme Court] (Dz.U. 1932 nr 110 poz. 91).

\section{German legislation}

Verordnung über den Aufbau der Rechtspflege im Generalgouvernement vom 26.10.1939 [Regulation on the reconstruction of the judiciary in the General Government of 26 October 1939] (Journal of the Regulations of the General Governor for the occupied Polish territories, no. 1, p. 4). [Dz.RGGOP, no. 1, p. 4].

Verordnung über Sondertgerichte im Generalgouvernement vom 15.11.1939 [Regulation on special courts in the General Government of 15 November 1939] (Journal of the Regulations of the General Governor for the occupied Polish territories, no. 6, pp. 34-6).

Verordnung über die Beschlagnahme von privaten Vermögen im Generalgouvernement (Beschlagnahmeordnung) vom 24.1.1940 [Regulation on the seizure of private property in the General Government (Confiscation Ordinance) of 24 January 1940] (Journal of the Regulations of the General Governor for the occupied Polish territories, part I, no. 6, pp. 23-7).

Verordnung über die Deutsche Gerichtsbarkeit im Generalgouvernement vom 19.2.1940 [Regulation on German judiciary in the General Government of 19 February 1940] (Journal of the Regulations of the General Governor for the occupied Polish territories, part I, no. 13, pp. 57-63). 
Verordnung über die Polnische Gerichtsbarkeit im Generalgouvernement vom 19.2.1940 [Regulation on the Polish judiciary in the General Government of 19 February 1940] (Journal of the Regulations of the General Governor for the occupied Polish territories, part I, no. 13, pp. 64-8).

Verordnung über den Übergang von Rechtssachen in der deutschen und polnischen Gerichtsbarkeit vom 19.2.1940 [Regulation on the transfer of legal matters in the German and Polish judiciary of 19 February 1940] (Journal of the Regulations of the General Governor for the occupied Polish territories, part I, no. 13, pp. 68-71).

Verordnung über den Verkehr mit Grundstücken im Generalgouvernement vom 27.3.1940 [Regulation on real estate transactions in the General Government of 27 March 1940] (Journal of the Regulations of the General Governor for the occupied Polish territories, part I, no. 23, pp. 115-7).

\section{Studies}

Becker, Maximilian. Mitstreiter im Volkstumskampf. Deutsche Justiz in den eingegliederten Ostgebieten 1939-1945. München: De Gruyter Oldenburg, 2014.

Biographical note of W. Zahajkiewicz. https://www.parlament.gv.at/WWER/PARL/J1848/Zahajkiewicz.shtml (access date: 23.10.2020).

Dębski, Jerzy. „Sędziowie polscy uwięzieni w KL Auschwitz”. Krakowskie Zeszyty Sądowe 17, no. 3 (2017): 22-3.

Dratwa, Krzysztof. „Losy krakowskich sędziów i prokuratorów podczas Drugiej Wojny Światowej". http://www.duszpasterstwoprawnikow.pl/index.php/dla-refleksji/50-artykul-p-prok-krzysztofa-dratwy-pt-losy-krakowskich-sedziow-i-prokuratorow-podczas-drugiej-wojny-swiatowej.html (access date: 23.10.2020).

Dziobek-Romański, Jacek. „Organizacja administracji władz okupacyjnych na ziemiach polskich w latach 1939-1945". Roczniki Nauk Prawnych 22, no. 3 (2012): 278-86.

Kowalski, Grzegorz M. „Zarys historii Sądu Apelacyjnego w Krakowie. Od zaborów po czasy współczesne". In Świat, Europa, mała Ojczyzna. Studia ofiarowane Profesorowi Stanisławowi Grodziskiemu w 80-lecie urodzin, ed. M. Małecki, 481-96. Bielsko-Biała: Wyższa Szkoła Administracji, 2009.

Kowalski, Grzegorz M. Sąd Apelacyjny w Krakowie. Księga jubileuszowa. Kraków: Sąd Apelacyjny, 2010.

Kozyra, Waldemar. „Okupacyjna administracja niemiecka na ziemiach Rzeczypospolitej Polski w latach 1939-1945", Annales UMCS. Sec. G IUS 41, no. 1 (2013): 36-42.

Lityński, Adam. Historia prawa Polski Ludowej. Warszawa: LexisNexis Polska, 2013.

Majer, Diemut. "Fremdvölkische" im Dritten Reich: ein Beitrag zur nationalsozialistischen Rechtssetzung und Rechtspraxis in Verwaltung und Justiz unter besonderer Berücksichtigung der eingegliederten Ostgebiete und des Generalgouvernements. München: Oldenbourg Verlag, 1993.

Makowski, Wacław. Kodeks karny 1932. Komentarz. 1. Część ogólna. Warszawa: nakładem Księgarni F. Hoesicka, 1932.

Malec, Dorota. „Sąd Najwyższy w latach 1917-1939”. In Sąd Najwyższy Rzeczypospolitej Polskiej. Historia i wspótczesność, ed. Artur Korobowicz, 121-191.Warszawa: Sąd Najwyższy Rzeczypospolitej Polskiej, 2007.

Mielnik, Hubert. „Prawo sprawdzenia prawomocnych orzeczeń sądów polskich (nieniemieckich) w Generalnym Gubernatorstwie w okresie II wojny światowej. Orzecznictwo Wyższego Sądu Niemieckiego w Radomiu". Czasopismo Prawno-Historyczne 72, no. 1 (2020): 211-39. DOI: 10.14746/cph.2020.1.12.

Mielnik, Hubert. Sadownictwo polskie (nieniemieckie) w dystrykcie lubelskim Generalnego 
Gubernatorstwa 1939-1944. Lublin: Wydawnictwo Uniwersytetu Marii Curie-Skłodowskiej, 2020.

Sworzeń, Marian. „Sądownictwo polskie w Generalnym Gubernatorstwie”. Prawo i Życie 40 (1987): 10-1.

Sworzeń, Marian. „Sędziowie w podbitym kraju. Oficjalne sądownictwo polskie w Generalnym Gubernatorstwie 1939-1945". Zeszyty Historyczne 128 (1999): 38-53.

Szarycz, Jan. Sędziowie i sądy w Polsce w latach 1918-1988. Warszawa: Ministerstwo Sprawiedliwości, 1988.

Szerkus, Oscar. Die Sondergerichtsbarkeit des Polnischen Untergrundstaates. Schriften zur Rechtsgeschichte, Band 183. Berlin: Duncker \& Humbolt, 2019.

Szulczyński, Andrzej. Sadownictwo polskie w Generalnym Gubernatorstwie 1939-1945. Warszawa: Słowo, 2020.

Turska, Anna. „Prawo państwa totalitarnego”. Studia Iuridica 22 (1992): 21-34.

Uruszczak, Wacław. „Perwersyjne funkcje niemieckiego «prawa» w Generalnym Gubernatorstwie (1939-1945)". Z dziejów prawa 20, no. 12 (2019): 681-707. DOI: 10.31261/ZDP.2019.20.40.

Wrzyszcz, Andrzej. „O organizacji okupacyjnego sądownictwa polskiego w Generalnym Gubernatorstwie w latach 1939-1945". Zeszyty Majdanka 14, (1992): 113-25.

Wrzyszcz, Andrzej. Okupacyjne sadownictwo niemieckie w Generalnym Gubernatorstwie 1939-1945. Organizacja i funkcjonowanie. Lublin: Wydawnictwo Uniwersytetu Marii Curie-Skłodowskiej, 2008. 